1 André O. Agostinis ${ }^{1,2, a}$, Giorgi Dal Pont ${ }^{2, a}$, Alexandre Borio ${ }^{1}$, Aline Horodesky ${ }^{1,2,3}$, Ana Paula da

2 Silva Bertão ${ }^{2}$, Otto Samuel Mäder Netto ${ }^{3,5}$, Thiago Luis Zanin ${ }^{4}$, Antonio Ostrensky ${ }^{2}$ \& Marcio

$3 \quad$ R. $\mathrm{Pie}^{1 *}$

4

An experimental assessment of the distribution of environmental DNA along the water

column

$8 \quad{ }^{1}$ Departamento de Zoologia, Universidade Federal do Paraná, Caixa Postal 19020, Curitiba, PR 9 81531-980, Brazil

10 2Grupo Integrado de Aquicultura e Estudos Ambientais, Departamento de Zootecnia,

11 Universidade Federal do Paraná, Curitiba, PR 80035-050, Brazil

$12{ }^{3}$ ATGC - Genética Ambiental Ltda, Curitiba, PR, 80035-050, Brazil.

$13{ }^{4}$ COPEL Geração e Transmissão S/A, GeT/SGE/DPEG/VECM, Brazil.

14 5 Aliança Prestadora de Serviços Ltda, Av. Sete de Setembro, 5402 CJ 41, Curitiba, PR, 80.240-

15 000, Brazil

16 aThese authors contributed equally to this work.

17 *Corresponding author: marcio.pie@gmail.com

ORCID ID: André O. Agostinis 0000-0002-0205-5465

20 ORCID ID: Giorgi Dal Pont 0000-0002-0306-5075

21 ORDIC ID: Alexandre Borio 0000-0003-4316-7495

22 ORCID ID: Aline Horodesky 0000-0002-5745-7090

23 ORCID ID: Ana Paula da Silva Bertão 0000-0001-7078-0848

24 ORCID ID: Otto Samuel Mäder Neto 0000-0003-2513-1683

25 ORCID ID: Antonio Ostrensky 0000-0001-8858-7552

26 ORDIC ID: Marcio R. Pie 0000-0002-2949-4871

\title{
28 Keywords
}

29 Freshwater; eDNA, Free DNA; DNA distribution; biodiversity monitoring. 
Abstract

31 The study of environmental DNA (eDNA) is increasingly becoming a valuable tool to survey

32 and monitor aquatic communities. However, there are important gaps in our understanding of the

33 dynamics governing the distribution of eDNA under natural conditions. In this report we carry

34 out controlled experiments to assess the extent and timing of eDNA distribution along the water

35 column. A sample of known eDNA concentration was placed at the bottom of a 5-m high tube

36 (20 cm in diameter and total volume of $160 \mathrm{~L})$, and water samples were obtained at different

37 depths over an 8 h-period. The presence of the target eDNA was assessed by qPCR analysis.

38 This sampling protocol allowed for assessing the timescale for the diffusion of eDNA while

39 minimizing the influence of turbulence. We demonstrate that, after a time-period of as little as 30

$40 \mathrm{~min}$, the eDNA had spread across the entire container. The implications of these results for

41 eDNA sampling protocols in the field are discussed.

42

43

44

45

46

47 


\section{Introduction}

Environmental DNA (eDNA) is a method based on the detection of trace genetic material

51 shed from organisms into their surroundings (Barnes and Turner 2016). Environmental DNA is

52 composed by a range of particles, such as free DNA, organelles, cells, tissue fragments and

53 metabolic waste (Turner et al. 2014; Wilcox et al. 2015). When suspended in an aquatic

54 environment, this material can be sampled together with the water, extracted, and detected

55 through molecular biology techniques (Ficetola et al. 2008). Surveillance and monitoring of

56 aquatic species through eDNA is widely applied with advantages over traditional methods. This

57 strategy, for example, can detect single or multiple species in one environmental sample (Harper

58 et al. 2018), and the results can quantify relative biomass (Pilliod et al. 2014; Takahara et al.

59 2012). The main advantages of this approach are the shorter time requirements, increased cost-

60 effectiveness, increased taxonomic resolution and non-invasive sampling (Eiler et al. 2018;

61 Hunter et al. 2015; Thomsen et al. 2012). Several studies applied this method for aquatic

62 organisms, such as fish (Miya et al. 2015), mussels and snails (Goldberg et al. 2013; Marshall

63 and Stepien 2019), jellyfish (Minamoto et al. 2017), sharks (Bakker et al. 2017), amphibians

64 (Pope et al. 2020) and arthropods (Toju and Baba 2018).

Although eDNA is a powerful technique, it is far from being standardized, as several methods are applied to capture and analyze field samples (Hinlo et al. 2017). Water samples,

67 methods consist mostly of sampling the water column or the sediment (Buxton et al. 2017;

68 Katano et al. 2017; Wittwer et al. 2018). However, studies rarely sample more than one depth,

69 and when they do, the only parameter to compare them is detection rates or biodiversity

70 (Andruszkiewicz et al. 2017; Yamamoto et al. 2016). Spread of eDNA horizontally was recently

71 explored by studying flow from rivers (Jo et al. 2019; Pont et al. 2018; Sansom and Sassoubre 
72 2017; Villacorta-Rath et al. 2020) but the vertical distribution is still fairly explored from a

73 functional perspective. Vertical zoning is the structuring of communities through layers of

74 species and communities across depths, which can potentially change dramatically in a matter of

75 meters (Chappuis et al. 2014). eDNA concentration, composition and spatial distribution is then

76 expected to vary as communities change through depth due to vertical zoning. While some

77 studies conclude that there is a negligible impact on the detection and composition (Cordier et al.

78 2019; Currier et al. 2018; Eichmiller et al. 2014; Harper et al. 2020; Lafferty et al. 2020) others

79 report differences (Andruszkiewicz et al. 2017; Cordier et al. 2019; Hänfling et al. 2016; Jeunen

80 et al. 2020; Kuehne et al. 2020; Lacoursière-Roussel et al. 2018; Lor et al. 2020; Minamoto et al.

81 2017; Moyer et al. 2014; Murakami et al. 2019; Sigsgaard et al. 2020; Uthicke et al. 2018;

82 Yamamoto et al. 2016; Zhang et al. 2020). These studies, however, vary significantly between

83 the water body architecture, water composition, depth sampled, sampling strategy, target

84 organism, detecting technique, extraction protocol and molecular marker. This leads to an

85 inconsistent pattern that can be interpreted as detection relies more on the organism's biology

86 than depth (Minamoto et al. 2017). However, these studies do not consider how eDNA moves

87 through the column as both (a) the sources of biological material are still in the water body,

88 releasing particles, at the same time that the particles that are still in the water are being degraded

89 and moved horizontally, and (b) they do not consider time as one of their variables, only depth.

Water bodies are complex systems with varied hydraulic dynamics. Studying the vertical

91 aspects of eDNA in a natural system is a difficult task due to many factors acting in the water

92 column at once (Jane et al. 2015). Flow, hyporheic exchanges, streambeds, surface-subsurface

93 exchange, sediment and colloidal interactions are some of these factors that contribute to this

94 complexity (Shogren et al. 2016; Shogren et al. 2019). Controlling these variables in a field 
95 experiment to understand how they affect the vertical dynamics of eDNA is not logistically

96 viable, so they must be studied individually in a controlled environment.

97 In this study, we aim to understand how free DNA behaves in a controlled water column. To

98 this end, we built a 5-m high and 20-cm diameter PVC tube, injected DNA at the bottom and

99 monitored how it spread through the water column for 8 hours. Understanding how eDNA

100 behaves in the water column is important to interpret species distribution in a water body and

101 improve sampling strategies. A controlled environment is ideal for this because one can

102 introduce variables as our understanding of these dynamics improves.

\section{Materials and Methods}

Experimental setup

We build an experimental apparatus to emulate the water column of lentic, freshwater conditions using a 5-m high polyvinyl chloride (PVC) pipe $(20 \mathrm{~cm}$ in diameter). We placed chromatographic septa at six depths (i.e. $0,1,2,3,4$, and $5 \mathrm{~m}$ ) to allow water sampling by the external side of the cylinder by using a medical sterile 1-mL syringes and thus minimizing the generation of turbulence in the water column inside the cylinder. Prior to each experiment, the entire apparatus was decontaminated in a two-step process. First, we used a dichloroisocyanurate

111 solution $\left(0.06 \mathrm{~g} \mathrm{~L}^{-1}\right)$ to thoroughly wash the pipe. We then rinsed away the chlorine with

112 previously treated DNA-free water. This treatment consisted of decontaminating the water with a

$11310 \%$ sodium hypochlorite solution $\left(0.2 \mathrm{~mL} \mathrm{~L}^{-1}\right)$, followed by chlorine neutralization using a $50 \%$

114 sodium thiosulfate solution $\left(0.1 \mathrm{~mL} \mathrm{~L}^{-1}\right)$. The second step was repeated three times in order to 115 ensure that there was no leftover chlorine in the system, coupled with a colorimetric method to detect chlorine after each washing (Zall et al. 1956). 
We generated a test solution of eDNA by amplifying a $\sim 100 \mathrm{bp}$ fragment of the COI gene from a genomic sample of the golden mussel Limnoperna fortunei (Mytilidae), which is an

119 organism commonly known for its biofouling impacts on hydraulic systems (Darrigran and

120 Damborenea 2011). Each assay was run in a $25 \mu \mathrm{L}$ final volume reaction, with concentrations:

$121 \quad 100 \mu \mathrm{M}$ each primer, $0.25 \mathrm{mM}$ dNTP mix, 1 U Platinum Taq DNA Polymerase, 1 X Platinum

122 Taq buffer and $2 \mathrm{mM} \mathrm{MgCl} 2$; Thermocycling conditions followed: 1 min at $95^{\circ} \mathrm{C}$ for initial

123 denaturation, followed by 40 cycles of denaturation at $95^{\circ} \mathrm{C}$ for $1 \mathrm{~min}$, annealing at $60{ }^{\circ} \mathrm{C}$ for 30

124 sec. and at $70{ }^{\circ} \mathrm{C}$ for $30 \mathrm{sec}$. To obtain a high DNA concentration for the stock test solution, we 125 carried several independent PCRs and the resulting products were pooled, quantified using Qubit

1264 fluorometer, and frozen at $-80^{\circ} \mathrm{C}$. Immediately before the beginning of the experiments, the

127 DNA solution thawed at room temperature, and each experiment used a $1 \mathrm{~mL}$ aliquot (2000 ng 128 of target DNA).

Each experiment began by filling the entire apparatus with DNA-free water up to $5 \mathrm{~m}$, followed by a 15 min period to allow for the water movement to subside. At this point, $1 \mathrm{~mL}$

131 water samples were then collected from each depth using disposable, DNA-free syringes to serve

132 as negative controls. The experimental solution aliquot was then injected at the base of the pipe

133 (5 m depth), and immediately, $1 \mathrm{~mL}$ samples were collected from all depths using disposable

134 syringes. Sampling was then repeated at $30 \mathrm{~min}, 1,2,4$ and 8 hours after the injection. The entire 
137

eDNA amplification and quantification

Each water sample from the experimental apparatus was processed for DNA extraction using a Solid Phase Reversible Immobilization (SPRI) protocol (DeAngelis et al. 1995). First, 1 $\mathrm{mL}$ of collected sample was incubated with a final concentration of $12.5 \%$ weight/volume PEG8000, $0.7 \mathrm{M} \mathrm{NaCl}$ and $0.02 \mathrm{mg} / \mathrm{mL}$ carboxylated magnetic beads at room temperature for $10 \mathrm{~min}$ to condense DNA and bind it onto the magnetic beads. Samples were then magnetized using a neodymium rare earth permanent magnets (NEB), and the supernatant was carefully removed using a micropipette. Samples were dried at room temperature, eluted into $100 \mu \mathrm{L}$ of TE Buffer and gently mixed. After unbinding DNA from the magnetic beads, samples were magnetized again and the supernatant containing DNA was removed and stored in individual vials.

After extraction, samples were quantified using rtPCR with a hydrolysis probe (TaqMan) targeting the $100 \mathrm{bp}$ fragment previously amplified COI fragment (Pie et al. 2017). Each assay was run in a $10 \mu \mathrm{L}$ final volume, with concentrations as follows: $75 \mu \mathrm{M}$ each primer, $25 \mu \mathrm{M}$ probe and 1 X QuantiNova Probe PCR Kit (Qiagen). Each sample was run in triplicate, with 3 $\mu \mathrm{L}$ of extract being used in each reaction. Cycling conditions were: $2 \mathrm{~min}$ at $95^{\circ} \mathrm{C}$ for enzyme activation, followed by 50 cycles of denaturation at $95^{\circ} \mathrm{C}$ for $5 \mathrm{~s}$, and combined annealing and extension at $60^{\circ} \mathrm{C}$ for $5 \mathrm{sec}$. Assay was run in RotorGeneQ 5plex+HRM (Qiagen). For quantification, a standard curve was built by running a six-order serial dilution of the stock solution previously quantified using Qubit, also performed in triplicate. Each run was analyzed using RotorGeneQ Series Software (Qiagen), with Quantification analysis. Threshold was calculated with automatic option, with a 0.35 upper bound limit, and quantification was done with slope correct mode. 
159

160

161

162

163

164

Analyses

We used two approaches to assess the vertical distribution of eDNA over time. First, we tested the relationship between depth and concentration using linear regressions for each experimental period and determined the time until this relationship became nonsignificant (i.e. DNA concentrations were homogeneous between depths) as an indication of non-homogeneous distribution of eDNA across the apparatus. Second, we fit cubic smoothing splines to each dataset (degrees of freedom $=4)$. Given that the final concentrations are unlikely to become precisely equal due to measurement error, we compared the observed data to re-sampled splines in which concentrations and depths were randomly shuffled ( $\mathrm{N}=1000$ pseudo-replicates). This procedure allowed for the generation of a visual expectation of the expected variation in concentration estimates given the inherent variability of the environmental setup used in our study. All analyses were carried out using R 4.0.2 (R Core Team 2020).

\section{Results}

The vertical distribution of experimental DNA at different time periods is shown in Figure 1. There was a significant relationship between depths and $\mathrm{Ct}$ immediately after the beginning of the experiments $(t=2.99, p=0.008)$ and after $30 \min (t=5.36, p=6.32 e-05)$, but that relationship became non-significant after $1 \mathrm{~h}(\mathrm{p}=0.48-0.98)$. This difference was accompanied by an increase in the DNA concentration across all depths in a manner consistent with the homogenization of DNA concentration throughout the entire apparatus. These results were consistent with the comparison between the splines fit to the observed data and those obtained from shuffled samples. The only two time periods that were outside the simulated data were 
181 immediately after and 30 min after the beginning of the experiments. Interestingly, in the latter,

182 the DNA distribution was midway between the state at $\mathrm{t}=0$ and the complete homogenization

183 found at the end of the experiments, with higher-than-expected concentrations up to $3 \mathrm{~m}$ from the

184 origin of the DNA.

\section{Discussion}

As eDNA studies become increasingly used to monitor different components of the aquatic biota, it is crucial to understand the factors determining the distribution of eDNA in the water column. In our study, we demonstrate that the diffusion of DNA along the water column takes place rapidly, in the time scale of minutes, even in the absence of turbulence. This result is

191 important given that, under field conditions, the water currents would tend to accelerate the

192 homogenization process. Thus, there does not seem to be "an optimal location" to obtain water 193 samples for eDNA analyses in a lentic system, as DNA tends to not accumulate in a specific part 194 of the water column. These results are intriguing, given that previous studies suggested a 195 differential accumulation of eDNA on either the surface (e.g. (Murakami et al. 2019) or the bottom (e.g. (Moyer et al. 2014), or even near the layer that the organism lives (e.g. (Minamoto et al. 2017). 
203 filter pore size. Although this distribution range seems to be constant between close-related taxa

204 (such as fish, (Barnes et al. 2020)), it seems to vary between different taxa (such as water fleas)

205 (Moushomi et al. 2019). This distribution also changes with time, as bigger particles tend to

206 break down into smaller particles (Murakami et al. 2019). As the sampling and processing

207 methods (volume used, filtration technique, time between sampling and water composition

208 measurements) in these comparative studies are not standardized, it is expected that particle size

209 distribution will play a major role in the results. The behavior of different particle sizes on the

210 water column is unknown. This is a potential source of bias on the sampling, as the captured

211 eDNA can differ significantly from true eDNA source amount on a determined sampling point,

212 because of pore size and volume configuration, and this error can vary between sampling points.

213 We also expect that the solubility of these different particles influences how they behave in

214 the water column. While most of the eDNA particles tend to have a hydrophilic nature, some are

215 hydrophobic. When considering colloidal particles in the water, eDNA particles can bind to it

216 and behave differently from how they would if they were suspended, mostly due to weight

217 changes. This can lead to accumulation in certain parts of the water column, or changing speed

218 of diffusion (Cai et al. 2006a; Cai et al. 2006b). When bound particles are too dense, it can also

219 promote deposition and accumulation of eDNA in the substrate (Zhai et al. 2019). Size of

220 suspended particles also influences this dynamic, as finer substrates tend to capture more eDNA

221 due to smaller pores (Shogren et al. 2016). This can lead to an effect of accidentally re-

222 suspending trapped eDNA into the water column while sampling, which can cause a sampling

223 bias where capturing water near the bottom is actually capturing the substrate (Turner et al. 2014;

224 Turner 2004). Hydrogeomorphic features of the system being studied should be assessed in order 
225

226

227

228

229

230

231

232

233

234

235

236

237

238

239

240

241

242

243

244

245

246

247

to evaluate slopes (which influence depth variations) and adsorption sites (which can sequester eDNA) (Fremier et al. 2019).

It is also important to emphasize that our results only pertain to a specific aspect of DNA distribution, namely the vertical diffusion process over time in the absence of water currents. The movement of water in lotic conditions might provide qualitatively different conditions, given that water velocity varies with depth. For instance, under laminar flow, water near the surface might include eDNA from farther upstream than those near the bottom (Curtis et al. 2020). However, as water speed becomes faster, the onset of turbulent flow might lead to homogenization of bottom and top water layers (Mächler et al. 2020). Water flow and stratification are also important

factors that can create different degrading zones in the water column (Curtis et al. 2020). Liquid flow is known to degrade eDNA due to mechanical forces (Levy et al. 1999). When hyporheic exchanges (water from the main river flow being exchanged with water kept in porous substrates) are considered, we would expect it to create less intense flow zones. These islands could potentially serve as less degrading spaces, where it would be more advantageous to sample near porous substrates both due to sequester of eDNA and due to irreversible sorption to bed sediment (Foppen et al. 2013). Little is known about the dynamic of these spaces regarding eDNA particles and their distribution. In another scenario, when there's permanent water column stratification (such as in the sea), depth becomes an important sampling factor (Jeunen et al. 2020). It is unknown if eDNA can pass these barriers (i.e. if convection is enough to break these barriers and homogenize eDNA). It's also unknown if there are clines through the same zones, causing in-between convection to cycle the water and homogenize the water in each water break.

While our results show the behavior of a monodisperse phase of eDNA particles in a relatively small water column, it highlights how this system would behave without interference. 
248 With so many factors acting at once in a complex water body system, it is important to break

249 down its components and understand how they behave separately, so we can build a better model

250 that can be incorporated in realistic field conditions. Understanding the interplay between

251 turbulence, colloidal particles and eDNA transport is a particularly important frontier of eDNA

252 research.

254 Acknowledgements

255

This paper presents part of the results of the P\&D project, code PD-06491-0383/2015,

257 executed by the Federal University of Paraná and Aliança Prestadora de Serviços Ltda and

258 funded by COPEL Geração e Transmissão SA, under the Research and Technological

259 Development Program of Electricity Sector, regulated by the National Electric Energy Agency

260 (Aneel). The authors declare that they have no conflict of interest.

261

\section{References}

263 Andruszkiewicz, E. A., L. M. Sassoubre \& A. B. Boehm, 2017. Persistence of marine fish environmental DNA and the influence of sunlight. PLoS One 12(9):e0185043.

265 Aneel, A. N. d. E. E., 2016. Plano de Dados Abertos, Informações Gerenciais - Tópico: Geração.

266 Bakker, J., O. S. Wangensteen, D. D. Chapman, G. Boussarie, D. Buddo, T. L. Guttridge, H.

267 Hertler, D. Mouillot, L. Vigliola \& S. Mariani, 2017. Environmental DNA reveals $7(1): 1-11$. 
Barnes, M. A., W. L. Chadderton, C. L. Jerde, A. R. Mahon, C. R. Turner \& D. M. Lodge, 2020. Environmental DNA.

Barnes, M. A. \& C. R. Turner, 2016. The ecology of environmental DNA and implications for conservation genetics. Conservation Genetics 17(1):1-17.

BONACICH, E. M., John, 1980. The economic basis of ethnic solidarity: Small business in the Japanese American community. Univ of California Press.

Buxton, A. S., J. J. Groombridge, N. B. Zakaria \& R. A. Griffiths, 2017. Seasonal variation in environmental DNA in relation to population size and environmental factors. Scientific reports 7(1):1-9.

Cai, P., Q.-Y. Huang \& X.-W. Zhang, 2006a. Interactions of DNA with clay minerals and soil colloidal particles and protection against degradation by DNase. Environmental science

Cai, P., Q. Huang, X. Zhang \& H. Chen, 2006b. Adsorption of DNA on clay minerals and \& technology 40(9):2971-2976. the main distribution pattern of littoral assemblages on rocky shores at a regional scale.

288 Cordier, T., F. Frontalini, K. Cermakova, L. Apothéloz-Perret-Gentil, M. Treglia, E.

289 Scantamburlo, V. Bonamin \& J. Pawlowski, 2019. Multi-marker eDNA metabarcoding survey to assess the environmental impact of three offshore gas platforms in the North Adriatic Sea (Italy). Marine environmental research 146:24-34. 
Currier, C. A., T. J. Morris, C. C. Wilson \& J. R. Freeland, 2018. Validation of environmental DNA (eDNA) as a detection tool for at-risk freshwater pearly mussel species (Bivalvia: Unionidae). Aquatic Conservation: Marine and Freshwater Ecosystems 28(3):545-558.

Curtis, A. N., J. S. Tiemann, S. A. Douglass, M. A. Davis \& E. R. Larson, 2020. High stream flows dilute environmental DNA (eDNA) concentrations and reduce detectability. Diversity and Distributions.

Darrigran, G. \& C. Damborenea, 2011. Ecosystem engineering impact of Limnoperna fortunei in South America. Zoological science 28(1):1-7.

DeAngelis, M. M., D. G. Wang \& T. L. Hawkins, 1995. Solid-phase reversible immobilization for the isolation of PCR products. Nucleic acids research 23(22):4742.

Eichmiller, J. J., P. G. Bajer \& P. W. Sorensen, 2014. The relationship between the distribution of common carp and their environmental DNA in a small lake. PloS one 9(11):e112611.

Eiler, A., A. Löfgren, O. Hjerne, S. Nordén \& P. Saetre, 2018. Environmental DNA (eDNA) detects the pool frog (Pelophylax lessonae) at times when traditional monitoring methods are insensitive. Scientific reports 8(1):1-9.

Ficetola, G. F., C. Miaud, F. Pompanon \& P. Taberlet, 2008. Species detection using environmental DNA from water samples. Biology letters 4(4):423-425.

Foppen, J. W., J. Seopa, N. Bakobie \& T. Bogaard, 2013. Development of a methodology for the application of synthetic DNA in stream tracer injection experiments. Water resources research 49(9):5369-5380. and retention of environmental DNA pulse releases in relation to hydrogeomorphic scaling factors. Environmental science \& technology 53(12):6640-6649. 
Goldberg, C. S., A. Sepulveda, A. Ray, J. Baumgardt \& L. P. Waits, 2013. Environmental DNA as a new method for early detection of New Zealand mudsnails (Potamopyrgus antipodarum). Freshwater Science 32(3):792-800.

Hänfling, B., L. Lawson Handley, D. S. Read, C. Hahn, J. Li, P. Nichols, R. C. Blackman, A. communities reflects long-term data from established survey methods. Molecular ecology 25(13):3101-3119.

Harper, K. J., K. D. Goodwin, L. R. Harper, E. L. LaCasella, A. Frey \& P. H. Dutton, 2020. Finding Crush: environmental DNA analysis as a tool for tracking the green sea turtle Chelonia mydas in a marine estuary. Frontiers in Marine Science 6:810.

Harper, L. R., L. Lawson Handley, C. Hahn, N. Boonham, H. C. Rees, K. C. Gough, E. Lewis, I. cristatus). Ecology and evolution 8(12):6330-6341.

Hinlo, R., D. Gleeson, M. Lintermans \& E. Furlan, 2017. Methods to maximise recovery of environmental DNA from water samples. PloS one 12(6):e0179251. Reed \& K. M. Hart, 2015. Environmental DNA (eDNA) sampling improves occurrence

334 Jane, S. F., T. M. Wilcox, K. S. McKelvey, M. K. Young, M. K. Schwartz, W. H. Lowe, B. H. two headwater streams. Molecular ecology resources 15(1):216-227. 
Jeunen, G. J., M. D. Lamare, M. Knapp, H. G. Spencer, H. R. Taylor, M. Stat, M. Bunce \& N. J. Gemmell, 2020. Water stratification in the marine biome restricts vertical environmental DNA (eDNA) signal dispersal. Environmental DNA 2(1):99-111.

Jo, T., H. Murakami, S. Yamamoto, R. Masuda \& T. Minamoto, 2019. Effect of water temperature and fish biomass on environmental DNA shedding, degradation, and size distribution. Ecology and evolution 9(3):1135-1146.

Katano, I., K. Harada, H. Doi, R. Souma \& T. Minamoto, 2017. Environmental DNA method for estimating salamander distribution in headwater streams, and a comparison of water sampling methods. PLoS One 12(5):e0176541.

Kuehne, L. M., C. O. Ostberg, D. M. Chase, J. J. Duda \& J. D. Olden, 2020. Use of environmental DNA to detect the invasive aquatic plants Myriophyllum spicatum and

Lafferty, K. D., A. E. Garcia-Vedrenne, J. P. McLaughlin, J. N. Childress, M. F. Morse \& C. L. Jerde, 2020. At Palmyra Atoll, the fish-community environmental DNA signal changes across habitats but not with tides. Journal of Fish Biology. D. M. Lodge, C. Hernandez, N. Leduc \& L. Bernatchez, 2018. eDNA metabarcoding as a new surveillance approach for coastal Arctic biodiversity. Ecology and evolution 8(16):7763-7777. 
Lor, Y., T. M. Schreier, D. L. Waller \& C. M. Merkes, 2020. Using environmental DNA (eDNA) to detect the endangered Spectaclecase Mussel (Margaritifera monodonta). Freshwater Science 39(4):000-000.

Mächler, E., A. Salyani, J.-C. Walser, A. Larsen, B. Schaefli, F. Altermatt \& N. Ceperley, 2020. Environmental DNA simultaneously informs hydrological and biodiversity characterization of an Alpine catchment. Hydrology and Earth System Sciences Discussions:1-30.

Marshall, N. T. \& C. A. Stepien, 2019. Invasion genetics from eDNA and thousands of larvae: A targeted metabarcoding assay that distinguishes species and population variation of zebra and quagga mussels. Ecology and evolution 9(6):3515-3538.

Minamoto, T., M. Fukuda, K. R. Katsuhara, A. Fujiwara, S. Hidaka, S. Yamamoto, K. Takahashi \& R. Masuda, 2017. Environmental DNA reflects spatial and temporal jellyfish distribution. PLoS One 12(2):e0173073.

Miya, M., Y. Sato, T. Fukunaga, T. Sado, J. Poulsen, K. Sato, T. Minamoto, S. Yamamoto, H. Yamanaka \& H. Araki, 2015. MiFish, a set of universal PCR primers for metabarcoding environmental DNA from fishes: detection of more than 230 subtropical marine species.

375 Moushomi, R., G. Wilgar, G. Carvalho, S. Creer \& M. Seymour, 2019. Environmental DNA size sorting and degradation experiment indicates the state of Daphnia magna mitochondrial and nuclear eDNA is subcellular. Scientific reports 9(1):1-9. 
Murakami, H., S. Yoon, A. Kasai, T. Minamoto, S. Yamamoto, M. K. Sakata, T. Horiuchi, H. environmental DNA from caged fish in a marine environment. Fisheries science $85(2): 327-337$.

Pie, M. R., P. R. STRÖHER, A. O. Agostinis, R. Belmonte-Lopes, M. Z. Tadra-Sfeir \& A. Ostrensky, 2017. Development of a real-time PCR assay for the detection of the golden mussel (Limnoperna fortunei, Mytilidae) in environmental samples. Anais da Academia Brasileira de Ciências 89(2):1041-1045.

Pilliod, D. S., C. S. Goldberg, R. S. Arkle \& L. P. Waits, 2014. Factors influencing detection of eDNA from a stream-dwelling amphibian. Molecular Ecology Resources 14(1):109-116.

Pont, D., M. Rocle, A. Valentini, R. Civade, P. Jean, A. Maire, N. Roset, M. Schabuss, H. Zornig \& T. Dejean, 2018. Environmental DNA reveals quantitative patterns of fish biodiversity for rare amphibians in Sierra Nevada meadows. Aquatic Conservation: Marine and

Sansom, B. J. \& L. M. Sassoubre, 2017. Environmental DNA (eDNA) shedding and decay rates to model freshwater mussel eDNA transport in a river. Environmental Science \& Technology 51(24):14244-14253. 
continuous flow-through column experiments. Journal of the Royal Society Interface 13(119):20160290.

Shogren, A. J., J. L. Tank, S. P. Egan, D. Bolster \& T. Riis, 2019. Riverine distribution of mussel environmental DNA reflects a balance among density, transport, and removal processes. Freshwater Biology 64(8):1467-1479.

Sigsgaard, E. E., M. R. Jensen, I. E. Winkelmann, P. R. Møller, M. M. Hansen \& P. F. Thomsen, 2020. Population-level inferences from environmental DNA - Current status and future perspectives. Evolutionary Applications 13(2):245-262.

Takahara, T., T. Minamoto, H. Yamanaka, H. Doi \& Z. i. Kawabata, 2012. Estimation of fish biomass using environmental DNA. PloS one 7(4):e35868.

Team, 2020. R: A Language and Environment for Statistical Computing, version 4.0. 2. Vienna, Austria: R Foundation for Statistical Computing. Verfügbar unter https://www R-project org.

Toju, H. \& Y. G. Baba, 2018. DNA metabarcoding of spiders, insects, and springtails for exploring potential linkage between above-and below-ground food webs. Zoological

421 Turner, C. R., M. A. Barnes, C. C. Xu, S. E. Jones, C. L. Jerde \& D. M. Lodge, 2014. Particle and Evolution 5(7):676-684. 
424 Turner, D., 2004. Effects of sedimentation on the structure of a phaeophycean dominated macroalgal community.

426

427

428

429

430

431

432

433

434

435

436

437

438

439

440

441

442

443

444

445

446

Uthicke, S., M. Lamare \& J. R. Doyle, 2018. eDNA detection of corallivorous seastar (Acanthaster cf. solaris) outbreaks on the Great Barrier Reef using digital droplet PCR. Coral Reefs 37(4):1229-1239.

Villacorta-Rath, C., C. Hoskin, J. Strugnell \& D. Burrows, 2020. Long distance (> 20 km) downstream detection of endangered stream frogs suggests an important role for eDNA in surveying for remnant amphibian populations. Authorea Preprints.

Wilcox, T. M., K. S. McKelvey, M. K. Young, W. H. Lowe \& M. K. Schwartz, 2015. Environmental DNA particle size distribution from Brook Trout (Salvelinus fontinalis). Conservation Genetics Resources 7(3):639-641.

Wittwer, C., C. Nowak, D. A. Strand, T. Vrålstad, M. Thines \& S. Stoll, 2018. Comparison of two water sampling approaches for eDNA-based crayfish plague detection. Limnologica 70:1-9.

Yamamoto, S., K. Minami, K. Fukaya, K. Takahashi, H. Sawada, H. Murakami, S. Tsuji, H. Hashizume, S. Kubonaga \& T. Horiuchi, 2016. Environmental DNA as a 'snapshot' of fish distribution: A case study of Japanese jack mackerel in Maizuru Bay, Sea of Japan. PLoS One 11(3):e0149786.

Zall, D. M., D. Fisher \& M. Q. Garner, 1956. Photometric determination of chlorides in water. Analytical Chemistry 28(11):1665-1668.

Zhai, H., L. Wang \& C. V. Putnis, 2019. Molecular-scale investigations reveal noncovalent bonding underlying the adsorption of environmental DNA on mica. Environmental science \& technology 53(19):11251-11259. 
447 Zhang, Y., M. Pavlovska, E. Stoica, I. Prekrasna, J. Yang, J. Slobodnik, X. Zhang \& E. Dykyi, 2020. Holistic pelagic biodiversity monitoring of the Black Sea via eDNA metabarcoding approach: From bacteria to marine mammals. Environment International 135:105307.

450

451

452

453

454

455

456

457

458

459

460

461

462

463

464

465

466

467

468

469 
bioRxiv preprint doi: https://doi. org/10.1101/20201130.402438. this version posted December 1 2020. The copyright holder for this preprint (which was not certified by peer review) is the author/funder, who has granted bioRxiv a license to display the preprint in perpetuity. It is made available under aCC-BY-ND 4.0 International license.

\section{$470 \quad$ Figure}

$471 \quad$ Fig. 1

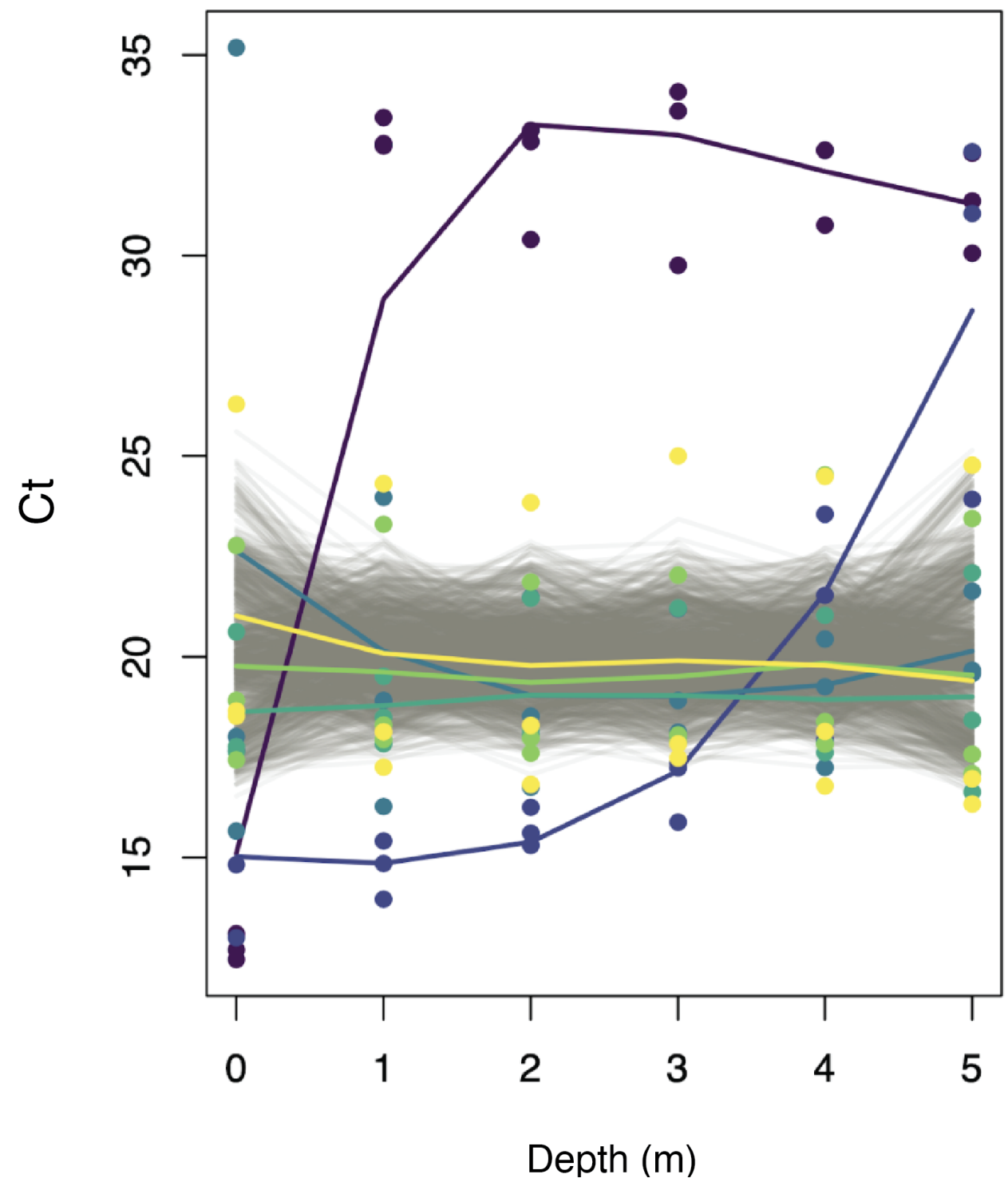

- $0 \mathrm{~h}$

$0.5 \mathrm{~h}$

- $1 \mathrm{~h}$

$2 \mathrm{~h}$

- $3 \mathrm{~h}$

- $8 \mathrm{~h}$ 


\section{Figure caption}

481 Fig. 1. Variation in threshold cycle $(\mathrm{Ct})$ in our experiments from immediately after the addition

482 of DNA $(\mathrm{t}=0 \mathrm{~h})$ to eight hours later. Colored lines show cubic splines across the three replicates

483 of each experimental group (see legend). Gray lines indicate 1000 similar splines with datasets in

484 which concentration and depth data were randomly shuffled. 